\title{
UJAWNIENIA ŚRODOWISKOWE W WYBRANYCH DOKUMENTACH GIEŁDOWYCH SPÓŁEK ENERGETYCZNYCH
}

\begin{abstract}
Streszczenie
Informacje środowiskowe w sprawozdaniach finansowych są niewystarczające do potrzeb zarządczych, dlatego w tym zakresie jest niezbędne raportowanie niefinansowe. Najczęściej do tego są wykorzystywane sprawozdania z działalności (SzD) i raporty CSR/środowiskowe. Stąd celem artykułu jest analiza zakresu informacji środowiskowych ujawnianych przez giełdowe spółki energetyczne w SzD po wprowadzeniu KSR numer $9 \mathrm{i}$ w raportach/sprawozdaniach środowiskowych pod kątem ich porównywalności (wewnątrzpodmiotowej i międzypodmiotowej) w kontekście wywiązywania się ze zobowiązań sprawozdawczych w tym zakresie. Okres badawczy to lata 2014-2016. W części wprowadzającej zastosowano metodę studiów literaturowych i aktów prawnych, a w empirycznej - analizę sprawozdań i raportów wybranych podmiotów, a także podejście indukcyjne przejawiające się w uogólnieniu wniosków wynikających z badań. Umożliwiło to wskazanie, który z podmiotów najlepiej wypełnia obowiązki związane z ujawnieniami środowiskowymi.
\end{abstract}

Słowa kluczowe: informacje środowiskowe, sprawozdanie z działalności, raport środowiskowy

\section{ENVIRONMENTAL DISCLOSURES IN SELECTED DOCUMENTS OF ENERGY COMPANIES}

\begin{abstract}
Summary
The environmental information included in financial statements is insufficient for management purposes, therefore non-financial reporting is required in this regard. The most commonly used forms include activity reports (CSDs) and CSR/environmental reports. Hence, the purpose of this paper is to analyze the scope of environmental information disclosed by listed energy companies (GDDs) after the introduction of CRS 9 and environmental reports in terms of their comparability (intra- and intercompany) as to the degree in which they meet the reporting obligations. The research covers the period of 2014-2016. In the introductory part, the method of literature review and legal studies is applied, while the empirical part offers an analysis of the reports submitted by selected entities, with conclusions of the research reached through an inductive approach. The author indicates which of the studied entities best fulfills the obligations related to environmental disclosures.
\end{abstract}

Key words: environmental information, activity report, environmental report

JEL classification: M41, Q56 


\section{Wstęp}

We współczesnej gospodarce kluczem do sukcesu są m.in.: zaufanie interesariuszy do przedsiębiorstwa, pozytywne relacje oraz przekonanie o społecznie odpowiedzialnej postawie danego podmiotu, również w zakresie zagadnień ekologicznych. Takie oczekiwania wobec przedsiębiorstwa stwarzają nowe sytuacje decyzyjne, a co za tym idzie, generują specyficzne zapotrzebowanie na informacje. Podejmowanie decyzji, a szerzej zarządzanie, wymaga odpowiedniego instrumentarium, to zaś odpowiednich informacji na różny temat. Instrumenty analityczne zarządzania, narzędzia informacyjne i służące komunikacji odgrywają istotną rolę w formułowaniu celów i sposobów ich realizacji, pomiaru wyników oraz rozliczania odpowiedzialności tak w odniesieniu do decyzji ekonomicznych, jak i zwiazanych z aspektami środowiska naturalnego. Okazało się, że informacje środowiskowe zawarte w sprawozdaniach finansowych są niestety niewystarczajace w warunkach zwiększonego na nie zapotrzebowania, dlatego coraz więcej uwagi poświęca się możliwościom, jakie dają w tym zakresie sprawozdanie z działalności i raporty środowiskowe. Stąd celem artykułu jest analiza zakresu informacji środowiskowych ujawnianych przez giełdowe spółki energetyczne w sprawozdaniach z działalności (SzD) po wprowadzeniu KSR numer $9 \mathrm{i}$ w raportach/sprawozdaniach środowiskowych pod kątem ich porównywalności (wewnątrzpodmiotowej i międzypodmiotowej) w kontekście wywiązywania się ze zobowiązań sprawozdawczych w tym zakresie. Podmiotem badań są spółki energetyczne notowane na Warszawskiej Giełdzie Papierów Wartościowych z dwóch powodów: (1) dostępność danych, które takie podmioty są zobligowane prezentować oraz (2) duże obciążenie środowiska związane z charakterem prowadzonej przez nie działalności. Przedmiotem badań są dostępne raporty społeczne (CSR)/środowiskowe i SzD z lat 2014-2016. Analiza porównawcza tych ostatnich umożliwiła odpowiedź na pytanie, czy wprowadzenie KSR numer 9 zdeterminowało przygotowywanie i zawartość informacyjną SzD oraz osiągnięcie postawionego celu. Realizacji celu posłużyło również syntetyczne przedstawienie istoty tych wybranych instrumentów raportowania środowiskowego.

\section{Instrumenty raportowania środowiskowego}

Aktualnie do najczęściej omawianych i wykorzystywanych instrumentów raportowania zagadnień środowiskowych należą SzD oraz stricte raporty społeczne przedsiębiorstwa, zawierające części ekologiczne lub samodzielne raporty/sprawozdania środowiskowe sporządzane według standardów GRI ${ }^{1}$. Ze względu na fakt poruszania tych zagadnień we wcześniejszych publikacjach oraz konieczność uniknięcia autoplagiatu zostaną podane tylko niezbędne informacje o tych instrumentach [Kryk, 2011, s. 253-270; Kryk, 2017, s. 108-117 ].

Raportowanie środowiskowe stanowi rozszerzenie sprawozdawczości firm, a jego celem jest komunikowanie ich dokonań w interesie poszczególnych grup interesariuszy

1 O tych zagadnieniach pisał m.in. [Dziawgo, 2010; 2014]. 
(rysunek 1.). Raportowanie jest związane $z$ upublicznieniem danych ekologicznych (m.in. o: oddziaływaniu na środowisko, ryzyku ekologicznym, prowadzonych działaniach proochronnych), które tradycyjnie nie sa prezentowane opinii publicznej. Publikacja takich danych wynika z postulatu jawności i transparentności działań organizacji.

Interesariusze raportowania środowiskowego $\mathrm{i}$ ich potrzeby

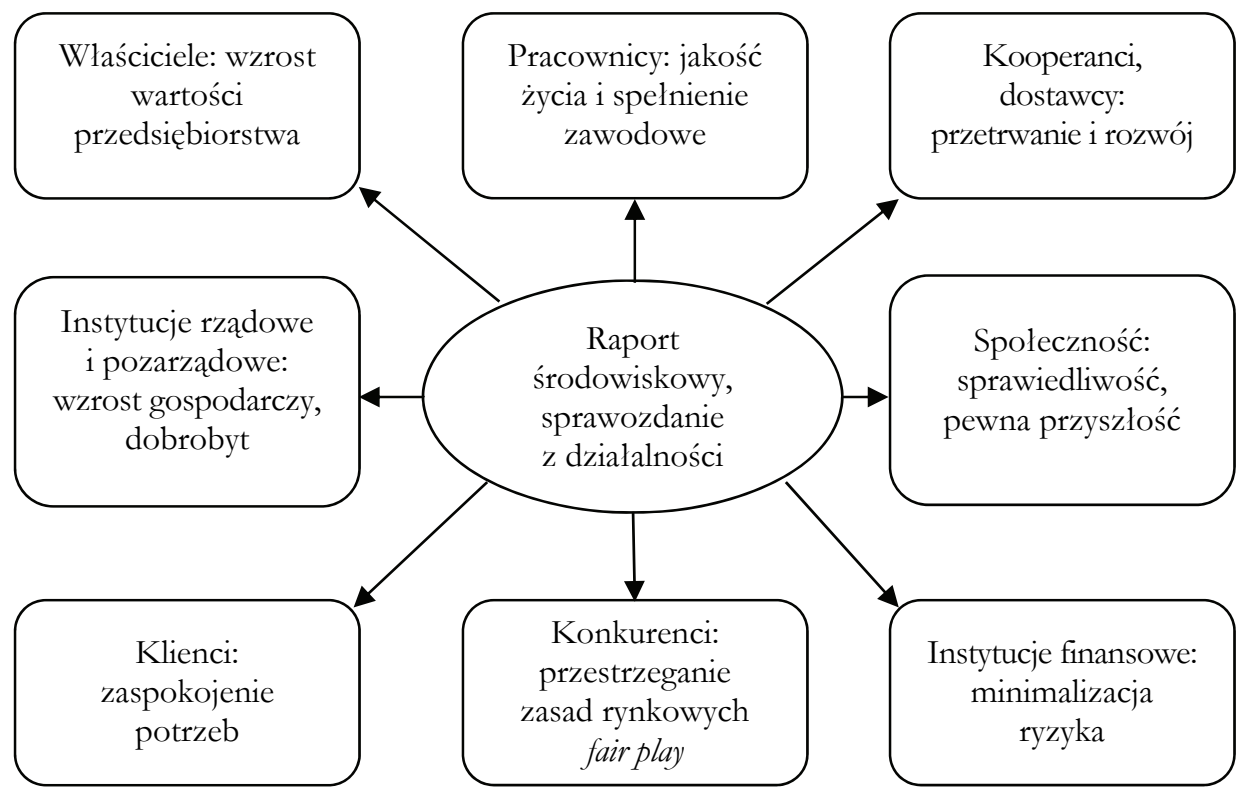

Źródło: opracowanie na podstawie: [Łukasiewicz, 2010, s. 14; Kryk, 2011a, s. 117].

Raportowanie środowiskowe, w ramach raportowania niefinansowego, coraz bardziej zyskuje na znaczeniu. Od 1 stycznia 2017 roku raportowanie niefinansowe stało się obowiazzkowe dla firm będących jednostkami zainteresowania publicznego, które zatrudniają ponad 500 osób i osiagnęły w poprzednim roku sumę bilansową powyżej $20 \mathrm{mln}$ euro lub przychody netto powyżej $40 \mathrm{mln}$ euro. W Polsce nowy wymóg sprawozdawczy dotyczy około 300 przedsiębiorstw². Wprowadzenie tego obowiązku jest konsekwencją wdrażania Dyrektymy Parlamentu Europejskiego $i$ Rady 2014/95/UE z dnia 22 października 2014 roku zmieniajacej dyrektywe 2013/34/UE w odniesieniu do ujawniania informacii niefinansowych $i$ informacji dotyczacych różnorodności przez niektóre duže jednostki oraz grupy (Dz. Urz. UE, 2014). Przy czym dyrektywa ta odnosi się zarówno do sprawozdań społecznych/środowiskowych, jak i SzD. W naszym kraju dodatkowo istnieją obligatoryjne i fakultatywne regulacje prawne, które obejmują SzD [por. Hońko, 2014, s. 122].

2 Główne zmiany, dotyczące raportowania informacji niefinansowych, są wprowadzane poprzez zmianę ustawy o rachunkowości, natomiast wymogi ujawniania polityki różnorodności w wyniku zmiany rozporządzenia Ministra Finansów w sprawie informacji bieżących i okresowych (Dz. U. 2016). 
Najważniejszym uregulowaniem obligatoryjnym jest Ustawa z dnia 29 września 1994 roku o rachunkowości ze zmianami (art. 49 i 55) (Dz. U. 2016). Nakłada ona obowiązek sporządzania SzD na: spółki kapitałowe, spółki komandytowo-akcyjne, towarzystwa ubezpieczeń wzajemnych, towarzystwa reasekuracji wzajemnej, spółdzielnie, przedsiębiorstwa państwowe, a także spółki jawne i komandytowe, których wszystkimi wspólnikami ponoszącymi nieograniczoną odpowiedzialność są: spółki kapitałowe, spółki komandytowo-akcyjne lub spółki z innych państw o podobnej do tych spółek formie prawnej. Zatem zgodnie z ustawa, SzD przygotowuja jednostki prowadzące działalność gospodarczą w określonej formie, bez względu na wielkość przychodów czy poziom zatrudnienia ${ }^{3}$. Natomiast grupy kapitałowe (jednostka dominująca), mające siedzibę albo miejsce sprawowania zarządu na terytorium Polski, są zobligowane do przygotowania skonsolidowanych sprawozdań rocznych grupy kapitałowej/raportów zintegrowanych obejmujących SzD.

Z kolei, najważniejszym dokumentem fakultatywnym, zawierającym wytyczne dotyczące SzD, jest Krajony Standard Rachunkowości (KSR) numer 9 „Sprawozdanie z działalności” (Dz. Urz. MF 2014). Ma on wspomóc przygotowanie SzD, zgodnego z przepisami ustawy o rachunkowości, odpowiadającego oczekiwaniom interesariuszy, promującego dobre praktyki w tym zakresie, stanowiącego uzupełnienie i dopełnienie sprawozdania finansowego. Standard ten najprecyzyjniej określa kto, kiedy i w jaki sposób powinien opracowywać SzD i prezentować, co powinno ono zawierać, czym się cechować, jakie spełniać zasady, ale bez podawania jednolitego, szczegółowego wzorca takiego raportu, przedstawiając dodatkowe użyteczne informacje ilościowe i jakościowe, finansowe i niefinansowe dotyczące działalności, wyników i sytuacji jednostki, których nie zawiera sprawozdanie finansowe, a mających znaczenie dla oceny osiagniętych wyników, aktualnej sytuacji oraz ich zmian na przyszłość. Wśród informacji istotne miejsce przypisano uwarunkowaniom środowiskowym, w szczególności o: gospodarowaniu zasobami i składnikami przyrody, wpływie jednostki na środowisko (w tym ryzykach i zagrożeniach środowiskowych), działaniach proekologicznych, opłatach środowiskowych $i$ innych kosztach $z$ tym związanych, proekologicznych przepisach prawnych, działaniach społecznych wraz z opisem kampanii społecznych i polityki jednostki w tym zakresie. W sprawozdaniu można wykorzystać zewnętrzne standardy i rekomendacje opracowane przez organizacje środowiskowe. W takiej sytuacji należy odwołać się do stosowanych dokumentów.

Niezależnie od omawianego aspektu, SzD powinno być: użyteczne, wiarygodne, przydatne, zrozumiałe oraz porównywalne w każdym zakresie, również środowiskowym [Krajony Standard Rachunkowości..., 2014]. Jednak należy przypomnieć, że zgodnie z art. 10, ust. 3 ustawy o rachunkowości, zarząd jednostki nie musi stosować KSR. Jeżeli się tego dobrowolnie podejmie, to będzie to miało przełożenie na sam fakt sporządzania sprawozdania oraz jego tematykę i zakres.

Do opracowywania raportów społecznych z aspektami ekologicznymi lub samodzielnych raportów środowiskowych dość powszechnie są wykorzystywane standardy

3 W przypadku jednostek mikro i małych, które mają obowiązek sporządzania sprawozdania z działalności zgodnie $z$ ust. 1 , mogą one nie sporządzać tego sprawozdania, pod warunkiem że w informacji dodatkowej przedstawią informacje dotyczące nabycia udziałów własnych. 
opracowane przez Światową Inicjatywę Sprawozdawczą (Global Reporting Initiative - GRI). Najnowsze i najpełniejsze wytyczne raportowania społecznego zostały oznaczone jako G44. Są to ogólnodostępne wytyczne, mające zastosowanie w sprawozdawczości pozafinansowej na temat: gospodarczych, ekologicznych i społecznych aspektów działalności, produktów i usług dowolnego przedsiębiorstwa (dane z tego zakresu są określane jako ESG5).Wersja G4 z 2016 roku zaczęła obowiązywać od 1 stycznia 2017 roku. Raport sporządzony według standardów GRI stanowi uzupełnienie do informacji zawartych w skonsolidowanym sprawozdaniu finansowym lub równoważnych dokumentach.

Budowanie raportu zgodnie $\mathrm{z}$ wytycznymi GRI powinno uwzględniać szereg zasad, zwłaszcza zasady: przejrzystości, włączenia, zrozumiałości, stosowności, kontekstu zrównoważonego rozwoju czy dokładności. Raporty nie mogą być wybiórcze w przedstawianiu informacji, powinny stanowić możliwie dobrze wyważoną ocenę osiagnięć przedsiębiorstwa, a raz wybrane granice i obszary raportu powinny być stałe. Informacje powinny być podane w formie zrozumiałej dla jak najliczniejszej grupy interesariuszy, a jednocześnie z zachowaniem odpowiedniego stopnia ich dokładności [szerzej: Global Reporting Initiative].

Wytyczne GRI ujmują wskaźniki szczegółowe w trzech kategoriach ${ }^{6}$ ekonomicznej, środowiskowej i społecznej. Kategoria środowiskowa opisuje wpływ organizacji na przyrodę ożywioną i nieożywiona, zawiera wyniki związane z: czynnikami produkcji, skutkami produkcji, wpływem na bioróżnorodność, przestrzeganiem zasad ochrony środowiska oraz inne istotne informacje, takie jak np. wydatki i inwestycje na ochronę czy wartość kar pieniężnych za nieprzestrzeganie prawa w tym obszarze. W ścisłym sensie wskaźniki w kategorii środowiskowej obejmują następujące elementy: Materiaty/Surowce (G4 - EN1 i EN2), Energie (G4 - EN3 do EN7), Wode (G4 - EN8 do EN10), Bioróżnorodność (G4 - EN11 do EN14), Emisje (G4 - EN15 do EN21), Ścieki i odpady (G4 - EN22 do EN26), Produkty i ustugi (G4 - EN27 i EN28), Zgodność z regulacjami (G4 - EN29), Transport (G4 - EN30), Ogólne (G4 - EN31), Ocene środowiskowa dostawcy (G4 - EN32 i EN33), Mechanizmy skargowe dotyczqce kwestii środowiskonych (G4 - EN34) [G4 Wytyczne dotyczace raportowania, 2016]. Wszystkie elementy powinny być uwzględniane przy sporządzaniu raportu.

Global Reporting Initiative, oprócz podziału na trzy kategorie, opublikowała dziesięć Suplementón sektorowych, w tym dla energetyki uznanej za jeden z kluczowych sektorów z racji odpowiedzialności względem gospodarki, społeczeństwa i środowiska. Zawartość tych Suplementów sektoronych została zaktualizowana, dzięki czemu można je wykorzystywać z Wytycznymi G47. Aktualizacja polegała m.in. na dodaniu do wszystkich elementów, we wszystkich kategoriach, uzupełnień w tym przypadku ściśle dotyczących sektora energetycznego.

4 Wersja G4 poszerza zakres raportowania społecznego (w porównaniu z wytycznymi G3) pod względem ich istotności w obszarze: angażowania interesariuszy w proces tworzenia raportu, podkreślenia roli łańcucha wartości oraz doboru treści, które powinny pojawić się w raporcie [Aluchna, Mikołajczyk, 2016].

5 Skrót ten oznacza: E - environment, S - social, G - governance.

6 Wskaźniki szczegółowe prezentują sposób zarządzania organizacją oraz jej wyniki w odniesieniu do istotnych aspektów.

7 Nowa wersja ma tytul: Suplementy sektorowe GRI [G4 Sector Disclosures]. 
Niezależnie od rodzaju przedsiębiorstw czy analizowanych aspektów, należy podkreślić, że GRI sugeruje, aby w ramach przygotowania raportu każda organizacja zadeklarowała poziom, który został osiagnięty w zakresie aplikacji Ramowych Zasad Raportowania GRI (tym też raport różni się od SzD). Określenie poziomu aplikacji zapewni czytelnikom/interesariuszom klarowną i jednoznaczną informację o tym, w jakim stopniu wytyczne tego standardu zostały zastosowane w danym raporcie, $\mathrm{z}$ uwzględnieniem stopniowego, rozłożonego w czasie rozszerzania zastosowania zasad tego raportowania. Stworzenie trzech poziomów (oznaczonych odpowiednio literami: C, B i A) pozwala sprostać potrzebom zarówno organizacji początkujących, średnio zaawansowanych, jak i tych najbardziej doświadczonych w tego typu sprawozdawczości. Ponadto, na każdym poziomie wprowadzono dodatkowe oznaczenie „,", potwierdzające dokonanie weryfikacji raportu przez zewnętrzny, niezależny organ potwierdzający, co stanowi swego rodzaju rekomendację rzetelności zaprezentowanych informacji.

Zasadniczo zawartość SzD i raportów społecznych uwzględniających aspekty środowiskowe może być podobna, natomiast inna będzie motywacja ich sporządzenia. W zależności od rodzaju i wielkości podmiotu, dla jednych nie będzie to już dobrowolną decyzja, lecz ustawowym obowiązkiem (i to zarówno w odniesieniu do opracowywania raportów, jak i sprawozdań), dla pozostałych - nadal będzie to wynikiem dobrowolnej, przemyślanej i własnej decyzji. Abstrahując od motywacji i instrumentu, ważne jest, by raportowanie informacji niefinansowych (tu środowiskowych) nie było sprawozdawczością pro forma i by odzwierciedlało faktyczne podejście/politykę przedsiębiorstwa do pewnych obszarów, ogólnie określanych jako ekologiczna odpowiedzialność biznesu.

\section{Analiza ujawnień środowiskowych w sprawozdaniach z działalności i raportach środowiskowych giełdowych spółek energetycznych}

Do badania wybrano jednostki objęte indeksem WIG-Energia. Jest ich 10 i prawie do wszystkich (oprócz INTERAOLT/Inter RaoLietuva AB i CEZ Polska Spółka z o.o., mających siedziby poza naszym krajem) odnoszą się przepisy ustawy o rachunkowości (art. 49 i 55), mówiące o sporządzaniu SzD. Polskie podmioty (8) są również objęte obowiązkiem przygotowywania raportów społecznych/środowiskowych, ale dopiero od bieżącego roku. W badanym okresie nie było to obligatoryjne. W tabeli 1 . zaprezentowano wyniki ujawnień środowiskowych w: (1) SzD z 2014 roku, kiedy wprowadzono KSR numer 9 i 2016 roku, aby sprawdzić, czy wpłynął on na przygotowywanie tych sprawozdań, (2) raportach społecznych/środowiskowych. 


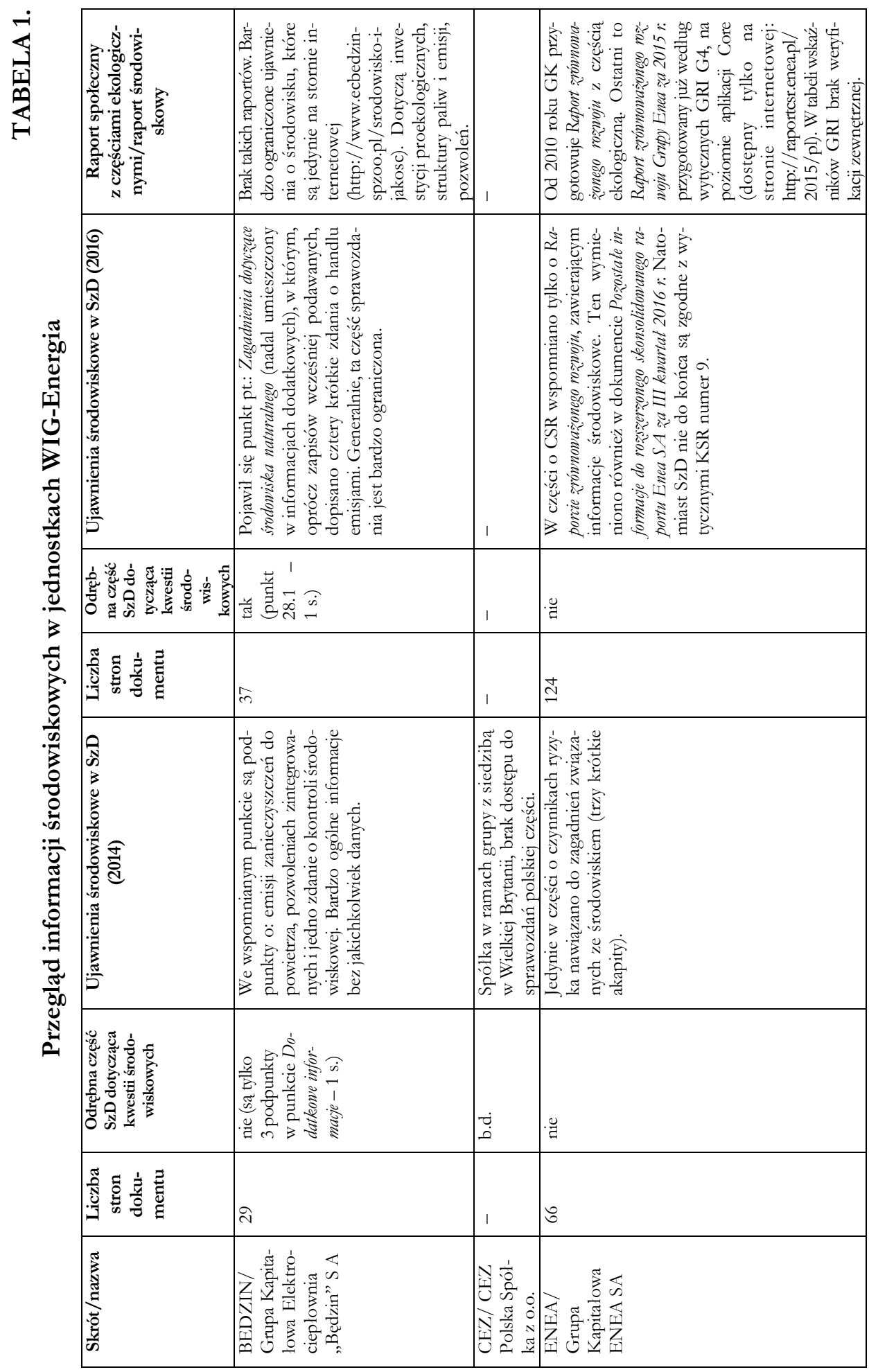




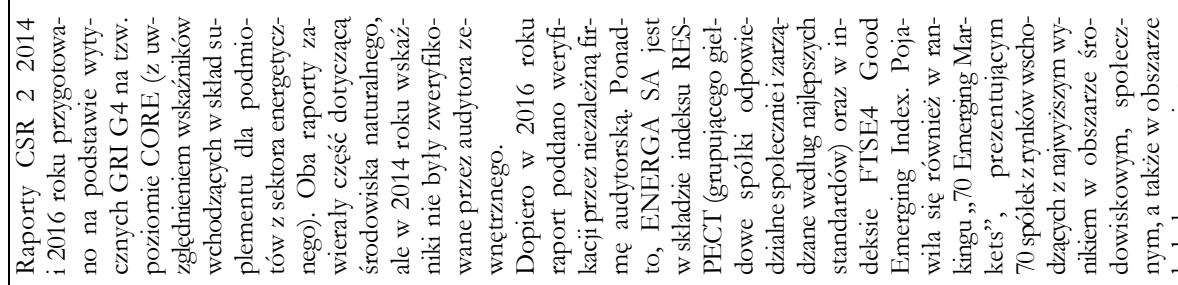

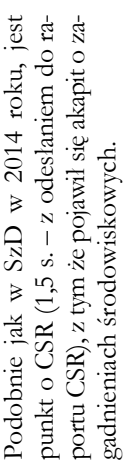

च

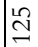

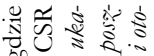

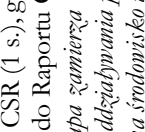

용

表苟 0

要

ำ

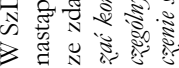

$\because$

กิ

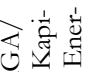

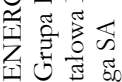




\begin{tabular}{|c|c|}
\hline । & 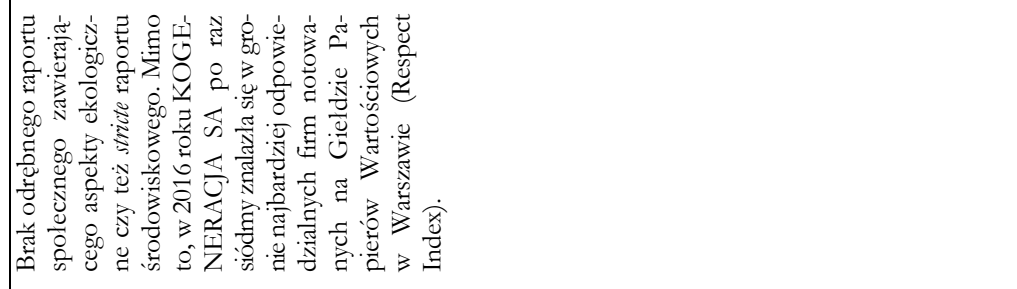 \\
\hline । & 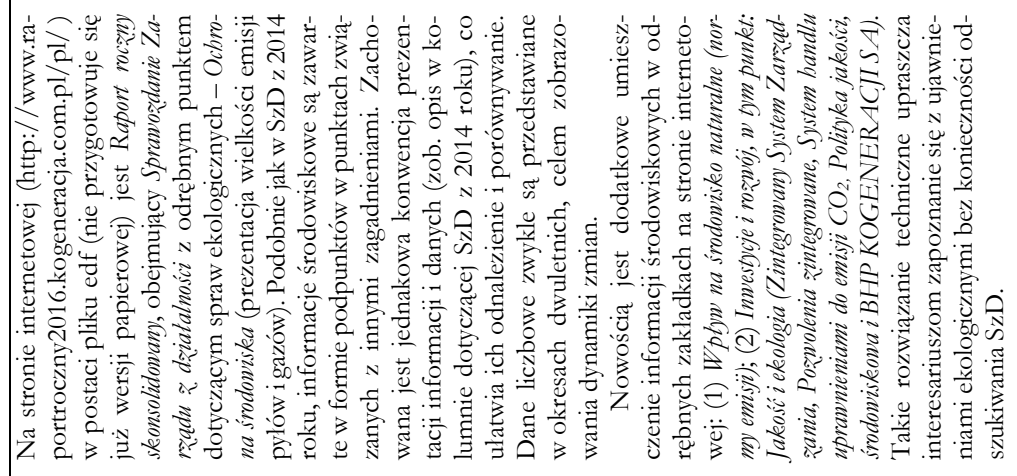 \\
\hline 1 & 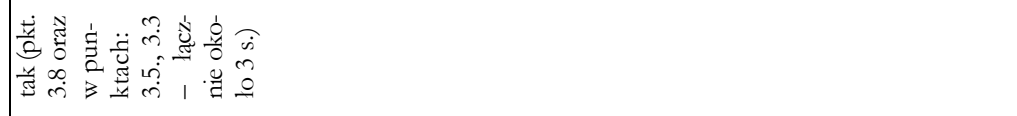 \\
\hline । & 8 \\
\hline & 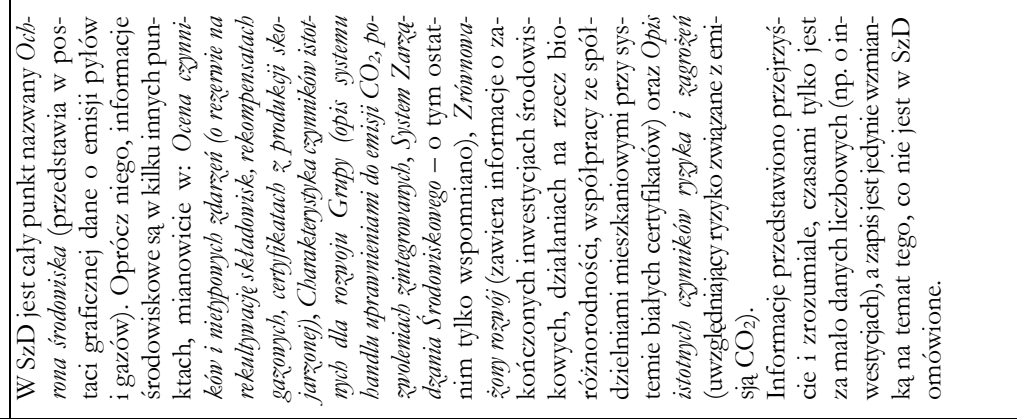 \\
\hline فٌذّ & 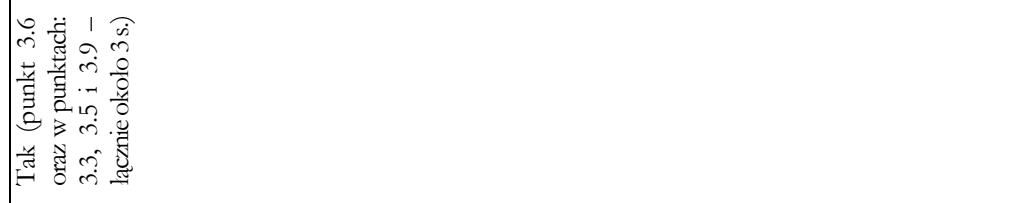 \\
\hline । & $\stackrel{\infty}{i n}$ \\
\hline 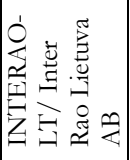 & 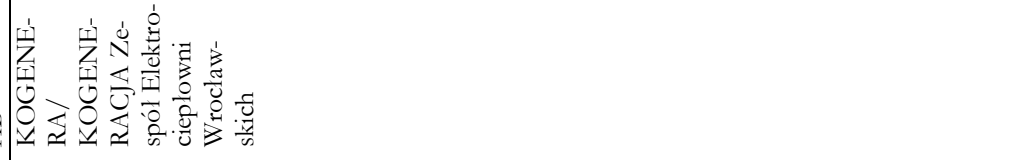 \\
\hline
\end{tabular}




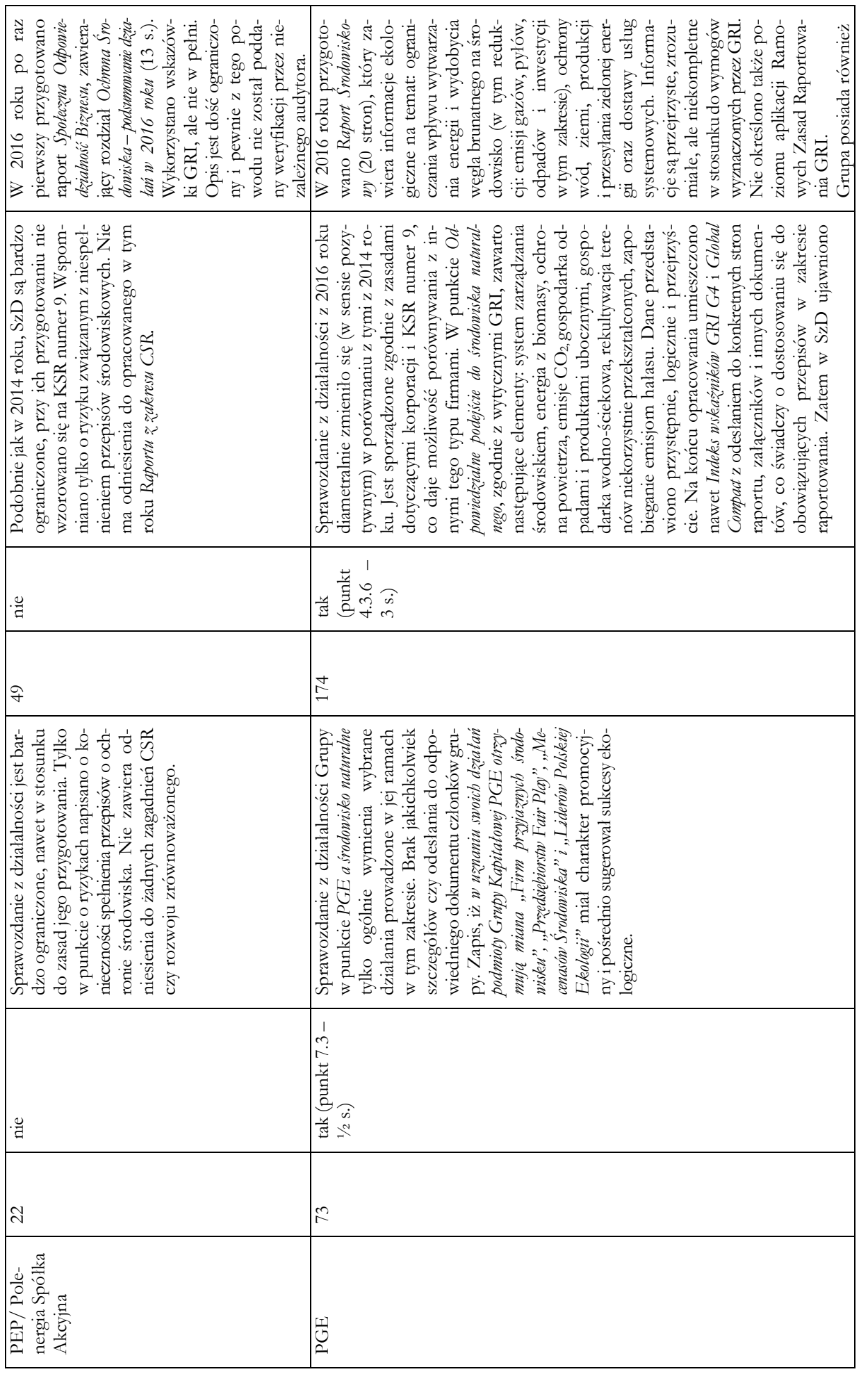




\begin{tabular}{|c|c|}
\hline 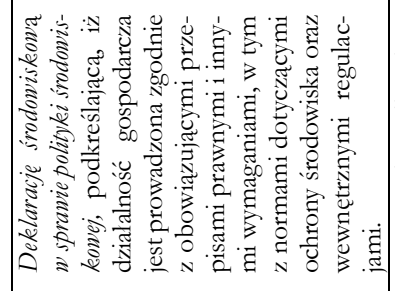 & 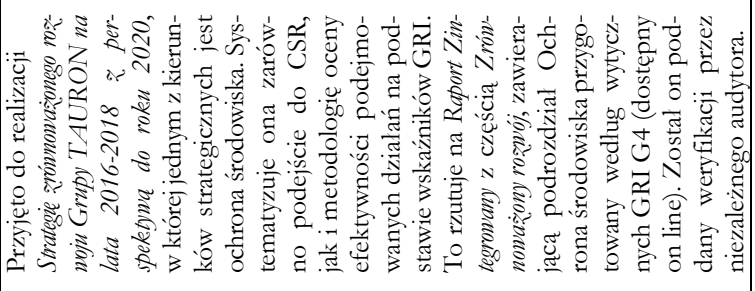 \\
\hline \multirow[t]{7}{*}{ 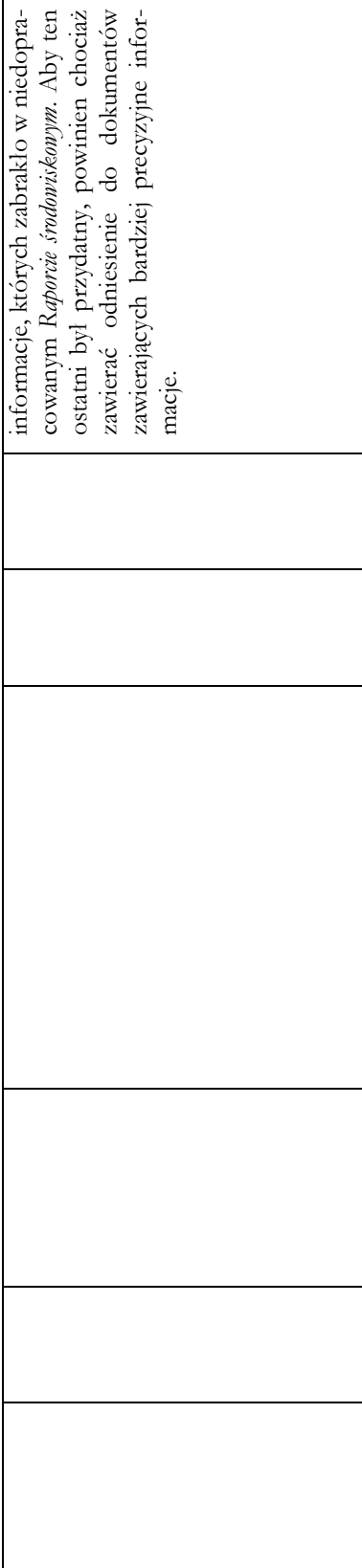 } & 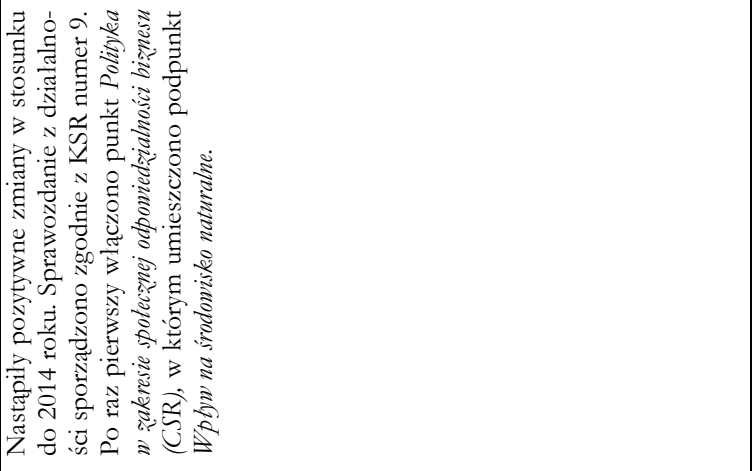 \\
\hline & 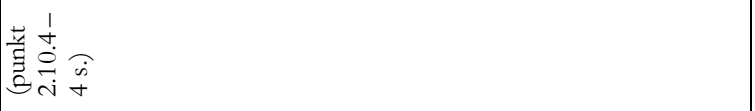 \\
\hline & 字 \\
\hline & 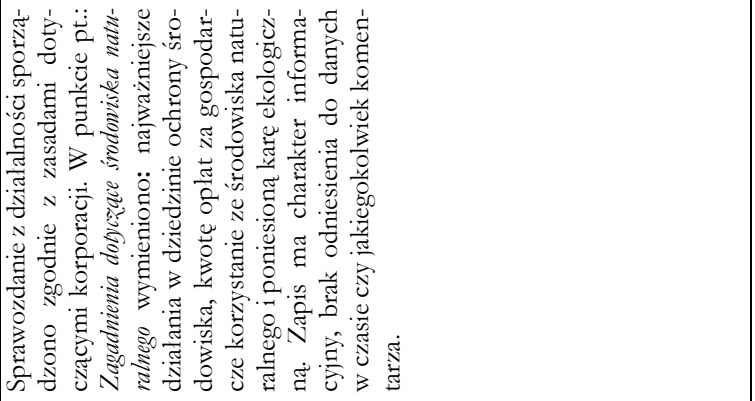 \\
\hline & 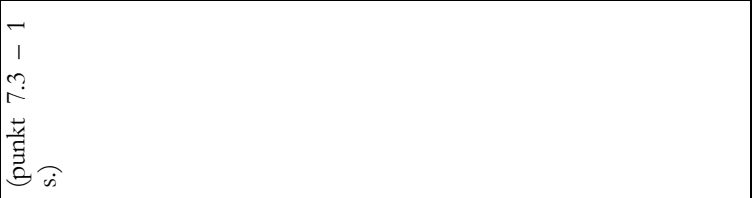 \\
\hline & $\stackrel{\text { g}}{\exists}$ \\
\hline & 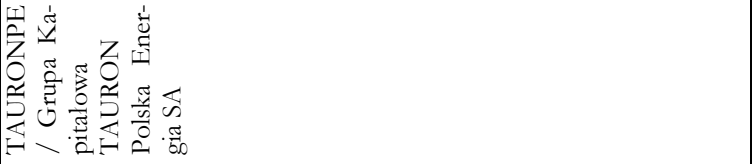 \\
\hline
\end{tabular}




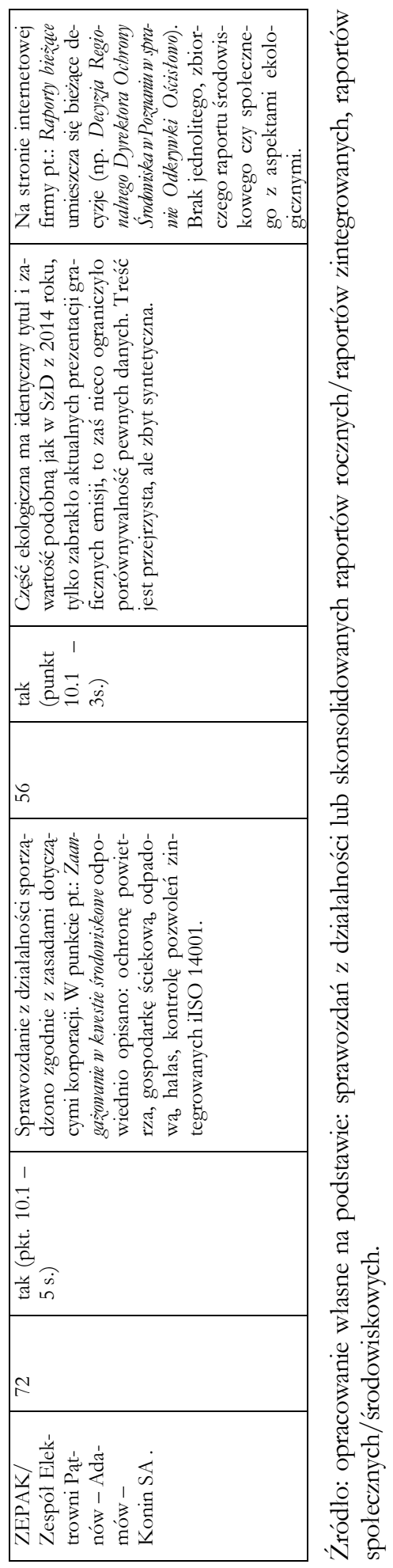


Z analizy wynika, że:

- $\quad$ w 2014 roku połowa badanych jednostek (PEP, ENERGA, ENEA, BEDZIN) nie miała wyodrębnionych części z informacjami środowiskowymi w SzD, natomiast w 2016 roku dotyczyło to trzech jednostek (BEDZIN uzupełnił sprawozdanie o taki punkt);

- $\quad$ w większości SzD był jeden punkt na ten temat, tylko w KOGENER-ze takie informacje wystapily w czterech punktach, średnio przeznaczano na to około dwie strony;

- $\quad$ w 2016 roku nastąpiły pozytywne zmiany w SzD, w porównaniu z tymi z 2014 roku, najistotniejsze dotyczyly: KOGENERY, PGE i TAURONU, które sporządziły sprawozdania zgodnie z KSR numer 9. Ich raporty zawieraja przejrzyste, porównywalne informacje i dane środowiskowe. W pozostałych podmiotach zmiany nie były tak spektakularne, ich SzD wymagaja dalszego udoskonalania i modyfikacji, gdyż większość ujawnień miała charakter opisowy, dość ogólny z niewielką ilością danych liczbowych, bez zachowania wskazówek zawartych w KSR numer 9. Ograniczoność zapisów ekologicznych powoduje, iż SzD pięciu jednostek w danym zakresie nie posiadały wszystkich cech od nich wymaganych (a wskazanych w standardzie), w tym przydatności i porównywalności;

- w 2016 roku raporty społeczne z częścią ekologiczna (zwane także raportami zrównoważonego rozwoju)/środowiskowe posiadało pięć z badanych ośmiu podmiotów (ENEA, ENERGA, PEP, PGE, TAURON), zostały one przygotowane na podstawie wytycznych GRI G4. Tylko dwa raporty (ENERGA i TAURONU) zostały zweryfikowane przez zewnętrznego audytora, zaś pozostałe nie były poddane takiej weryfikacji.

Generalnie, w 2016 roku większość badanych podmiotów starało się sporządzić SzD zgodnie z wytycznymi KSR numer 9, uwzględniając informacje środowiskowe, tylko stopień dopasowania do wytycznych standardu był różny. Z tego powodu nie wszystkie sprawozdania posiadały wymagane cechy. Podobnie było w przypadku raportów środowiskowych, ponad połowa badanych je opracowała i to na podstawie wytycznych GRI G4, ale tylko dwóch badanych sprostało wymogom audytorów.

\section{Podsumowanie}

Przeprowadzona analiza zakresu i prawidłowości ujawnień środowiskowych w SzD i raportach środowiskowych jest podstawą do syntetycznej oceny wywiązywania się ze zobowiązań sprawozdawczych w tym zakresie. Do jej wykonania wykorzystano następującą skalę ocen: niezadowalająca $(+)$, średnio zadowalająca $(++)$, dość zadowalająca $(+++)$, zadowalająca $(++++)$. W tabeli 2 . przedstawiono liczbę plusów możliwych do osiagnięcia w odniesieniu do SzD i raportów środowiskowych przez poszczególne podmioty, która determinuje jego ocenę ostateczną. Natomiast w tabeli 3. zaprezentowano wyniki syntetycznej oceny podmiotów w badanym zakresie. 
TABELA 2.

Liczba plusów możliwych do osiągnięcia przez jednostkę

\begin{tabular}{|c|c|}
\hline Rodzaj oceny & Przez jednostkę \\
\hline Niezadowalająca & $2-3$ \\
Średnio zadowalająca & $4-5$ \\
Średnio zadowalająca & $6-7$ \\
Zadowalająca & $\mathbf{8}$ \\
\hline
\end{tabular}

Źródło: opracowanie własne.

TABELA 3.

Syntetyczna ocena wywiązywania się podmiotów ze zobowiązań sprawozdawczych dotyczących środowiska

\begin{tabular}{|l|c|c|c|}
\hline \multicolumn{1}{|c|}{ Podmiot } & SzD & $\begin{array}{c}\text { Raporty środowi- } \\
\text { skowe }\end{array}$ & $\begin{array}{c}\text { Lączna liczba } \\
(+) / \text { ocena }\end{array}$ \\
\hline BEDZIN & + & + & 2 \\
ENEA & + & ++ & 3 \\
ENERGA & + & +++ & 4 \\
KOGENERA & +++ & + & 4 \\
PEP & + & ++ & 3 \\
PGE & +++ & +++ & 6 \\
TAURONPE & +++ & ++++ & 7 \\
ZEPAK & +++ & + & 4 \\
\hline
\end{tabular}

Źródło: opracowanie własne.

Biorąc pod uwagę powyższe, można sformułować poniższe wnioski.

1. W 2016 roku trzy podmioty (tj. 37,5\% badanych) miały ocenę niezadowalająca w zakresie wywiązywania się ze zobowiązań sprawozdawczych dotyczących środowiska, taka sama liczba miała ocenę średnio zadowalająca, a tylko dwa (25\%) uzyskały zadowalającą.

2. Sprawozdania $z$ działalności i raporty środowiskowe połowy podmiotów jeszcze nie posiadały cech wyznaczonych standardami, co oznacza konieczność ich doskonalenia.

Niezależnie od tego, ile jeszcze starań jest potrzebnych, by SzD i raporty osiagnęły wymagane cechy oraz poziom dokładności, pozytywne jest to, że podmioty gospodarcze zaczęły je opracowywać i traktować jako czynnik determinujący ich postrzeganie i funkcjonowanie na rynku. Duże znaczenie w tym ,skłanianiu” przedsiębiorstw do sporządzania raportów środowiskowych zgodnych ze standardami z pewnością mają instrumenty administracyjno-prawne, które precyzują nie tylko terminy wdrażania określonych rozwiązań, ale również konsekwencje związane z brakiem ich stosowania. 


\section{Literatura}

Aluchna M., Mikołajczyk O., 2016, Akcjonariusze vs. interesariusze. Przypadek raportowania zintegrowanego, „Prace Naukowe Uniwersytetu Ekonomicznego we Wrocławiu”, nr 436.

Dziawgo L., 2014, Greening financial market, "Copernican Journal of Finance \& Accounting", vol. 3, no. 2.

Dziawgo L., 2010, Zielony rynek finansowy, Polskie Wydawnictwo Ekonomiczne, Warszawa.

Dyrek.tywa Parlamentu Europejskiego i Rady 2014/95/UE z.dnia 22 października 2014 roku zmieniajaca dyrektywe 2013/34/UE w odniesieniu do ujawniania informacji niefinansowych i informacji dotyczacych różnorodności przez niektóre duże jednostki oraz.grupy, Dz. Urz. UE, 15.11.2014.

G4 Sector Disclosures, https://www.globalreporting.org/information/g4/sector-guidance/ sectorguidanceG4/Pages/default.aspx (data wejścia: 10.06.2017).

G4 Wytyczne dotyczqce raportowania, 2016, GRI, pdf, http://pihrb.org/28-06-2016wytyczne-raportowania-gri-g4-juz-po-polsku/ (data wejścia: 10.06.2017).

Hońko S., 2014, Sprawozdanie z. driałalności jako źródto informacji o oddzialywaniu jednostki na środowisko, „Ekonomia i Środowisko”, nr 3(50).

Global Reporting Initiative - cayli troche o raportowaniu spolecznym, http:/ / odpowiedzialny biznes.pl/artykuly/global-reporting-initiative-czyli-troche-o-raportowaniu-spolecznym (data wejścia: 10.06.2017).

Krajowy Standard Rachunkowości nr 9 „Sprawozdanie z driatalności”. Załacznik do uchwaty nr 6 Komitetu Standardów Rachunkowości z dnia 15 kwietnia, 2014, Dz. Urz. Ministra Finansów, poz. 17, Warszawa.

Kryk B., 2011, Raportowanie spotecznej odpowiedzialności przedsiębiorstw za środowisko prayrodnicze, „Zeszyty Naukowe nr 625 Finanse, Rynki finansowe, Ubezpieczenia”, nr 32.

Kryk B., 2011a, Strategia ekologizacji przedsiębiorstwa a raportowanie społecznej odpowiedzialności za środowisko, [w:] Inżnieria produkcji, prz̨edsięwriecia proekologiczne, ergonomia i bezpiecz̨eństwo pracy, M. Dudek, H. Howaniec, W. Waszkielewicz (red.), Akademia TechnicznoHumanistyczna w Bielsku-Białej, Bielsko-Biała.

Kryk B., 2017, Informacje środowiskowe w sprawozdaniach z. driałalności, "Prace Naukowe UE we Wrocławiu” nr 479.

Lukasiewicz G., 2010, Rola driatu personalnego w raportowaniu społecznej odpowiedzialności przedsiebiorstw, [w:] Problemy pracy i polityki spolecznej, B. Szopa (red.), Wydawnictwo Uniwersytetu Ekonomicznego w Krakowie, Kraków.

Rozporzqdzenie Ministra Finansów z dnia 25 maja 2016 roku zmieniajace rozporzqdzenie w sprawie informacji bieżacych i ok resowych przekazywanych przez. emitentów papierów wartościowych oraz warunków uznawania za równoważne informacji wymaganych przepisami prawa państwa niebędacego państwem członkowskim, Dz. U. 2016, poz. 860.

Ustawa z. dnia 29 września 1994 roku o rachunkowości, Dz. U. 2016, poz. 1047 ze zm. 